\title{
Expression of Glucocorticoid Receptor $\alpha$ and Its Regulation in the Bovine Endometrium: Possible Role in Cyclic Prostaglandin F2a Production
}

\author{
Mariko KUSE ${ }^{1) *}$, Hwa-Yong LEE ${ }^{1) *}$, Tomas J. ACOSTA ${ }^{1)}$, Takuo HOJO ${ }^{1)}$ and Kiyoshi OKUDA ${ }^{1)}$ \\ 1) Laboratory of Reproductive Endocrinology, Graduate School of Natural Science and Technology, Okayama University, \\ Okayama 700-8530, Japan
}

\begin{abstract}
Cortisol (Cr), the most important glucocorticoid (GC), is well known to suppress uterine prostaglandin F2 $\alpha$ (PGF) production. However, the details of the regulatory mechanisms controlling the cyclic changes in endometrial PGF production remain unclear. Here we investigated the expression of the $\mathrm{GC}$ receptor (GC-R $\alpha$ ), the actions of cortisol throughout the estrous cycle and the regulatory mechanism of GC-R $\alpha$ in the bovine endometrium. The levels of GC-R $\alpha$ protein were greater at the mid-luteal stage (Days 8-12) than at the other stages. Cr more strongly suppressed PGF production at the mid-luteal stage than at the follicular stage. GC-R $\alpha$ expression was increased by progesterone (P4) but decreased by estradiol-17 $\beta$ (E2) in cultured endometrial stromal cells. The overall results suggest that ovarian steroid hormones control the cyclic changes in endometrial PGF production by regulating GC-R $\alpha$ expression in bovine endometrial stromal cells.
\end{abstract}

Key words: Cattle, Endometrium, GC-R $\alpha$, Prostaglandins, Steroids

(J. Reprod. Dev. 59: 346-352, 2013)

$\mathbf{T}$

he bovine endometrium synthesizes and secretes prostaglandin

F2 $\alpha$ (PGF), which is the main luteolysin responsible for regression of the corpus luteum (CL). In nonpregnant cows, the uterus increases PGF production between days 17 and 19 postovulation [1]. The increase in uterine PGF production and its pulsatile release seem to regulate the estrous cycle by inducing luteal regression in ruminants [2-4]. We reported that the amount of PGF production by the bovine endometrium was low at the mid-luteal stage, increased at the late-luteal stage and reached the highest levels at estrus [5]. Thus, PGF production and secretion by the endometrium seem to be precisely regulated throughout the estrous cycle.

Glucocorticoids (GCs) derived from the adrenal cortex have been shown to regulate female reproductive functions $[6,7]$. Recently, we suggested that an active $\mathrm{GC}$, cortisol (Cr), affects pregnancy rate and $\mathrm{CL}$ function in cattle [8]. In addition, $\mathrm{Cr}$ suppresses basal and tumor necrosis factor- $\alpha$-stimulated PGF production in bovine endometrial stromal cells but not in the epithelial cells [9]. Moreover, 11ß-hydroxysteroid dehydrogenases (HSD11B) play an important role in regulating GC availability in target tissues. HSD11B type 1 mainly converts cortisone to $\mathrm{Cr}$ in the target organs $[10,11]$. A previous study demonstrated that the activity of HSD11B in the bovine endometrium was greater at the follicular stage and estrus than at the other stages of the estrous cycle [9]. In addition, PGF increased the protein expression of HSD11B in bovine endometrial stromal cells [9]. The above findings suggest that $\mathrm{Cr}$ plays some important

Received: December 10, 2012

Accepted: March 15, 2013

Published online in J-STAGE: April 6, 2013

(C)2013 by the Society for Reproduction and Development

Correspondence: TJ Acosta (e-mail: acosta@cc.okayama-u.ac.jp)

* M Kuse and HY Lee contributed equally to this work. roles in regulating PGF production throughout the estrous cycle in the bovine endometrium.

The above findings raise the possibility that the intracellular availability of $\mathrm{Cr}$ increases and that PGF production is thereby suppressed when HSD11B expression and activity are high at the follicular stage. However, PGF production by the bovine endometrium is highest at the follicular stage [5,9]. These results suggest that the inhibitory effect of $\mathrm{Cr}$ on PGF production depends on other factors. The biological action of $\mathrm{Cr}$ is mediated through the activation of specific intracellular receptors, GC receptors (GC-R) [12-16]. Because $\mathrm{Cr}$ actions depend on the expression of GC-R $\alpha$ in the target organs, endometrial PGF production appears to be regulated by not only changes in the levels of active $\mathrm{GC}(\mathrm{Cr})$ but also changes in GC-R $\alpha$ expression throughout the estrous cycle. However, the regulatory mechanisms controlling the cyclic changes in endometrial PGF production remain unclear.

Progesterone (P4) and estradiol-17 $\beta$ (E2) secreted by the ovary play crucial roles in regulating functional and structural changes in the endometrium throughout the estrous cycle [17]. Furthermore, in ruminants, the uterine epithelium, stroma and myometrium all contain receptors for P4 and E2 [18]. Thus, we hypothesize that P4 and $\mathrm{E} 2$ regulate $\mathrm{GC}-\mathrm{R} \alpha$ expression, which plays an important role in controlling PGF production in the bovine endometrium.

In the present study, to determine the regulatory mechanisms of PGF production in the bovine endometrium, we investigated 1) $\mathrm{GC}-\mathrm{R} \alpha$ protein expression and the biological actions of $\mathrm{Cr}$ in the bovine endometrium throughout the estrous cycle and 2) the roles of steroid hormones in the regulation of GC-R $\alpha$ expression in bovine endometrial stromal cells. 


\section{Materials and Methods}

\section{Collection of endometrial tissues}

Apparently healthy uteri of Holstein cows without a visible conceptus were obtained at a local slaughterhouse within 10-20 min of exsanguinations in accordance with protocols approved by the local institutional animal care and use committee. The stages of the estrous cycle were confirmed by macroscopic observation of the ovary and uterus as described previously [5, 19]. For protein determination, endometrial tissues ( $n=3 /$ stage) were collected from cows at six different stages of the estrous cycle (estrus, day 0; early-luteal, days 2-3; developing, days 5-6; mid-luteal, days 8-12; late-luteal, days 15-17 and follicular stage, days 19-21). Intercaruncular endometrial tissues from the uterine horn, ipsilateral to the CL, were used for experiments. The endometrial tissues were immediately frozen in liquid nitrogen, and stored at $-80 \mathrm{C}$ until processed for protein isolation. For experiments involving tissue culture and cell culture, the uteri were submerged in ice-cold physiological saline and transported to the laboratory within $1-1.5 \mathrm{~h}$ on ice.

\section{Culture of endometrial tissues}

For tissue culture, endometrial tissues were obtained at the midluteal stage and at the follicular stage. Endometrial tissue culture was conducted as described previously [9]. Briefly, endometrial strips were washed three times in sterile saline solution containing penicillin $(100 \mathrm{IU} / \mathrm{ml})$ and streptomycin $(100 \mu \mathrm{g} / \mathrm{ml})$. The tissues were finally cut into small pieces ( 40 to $50 \mathrm{mg}$ ) with a scalpel and subsequently washed another three times in Hank's balanced salt solution supplemented with penicillin (100 IU/ml), streptomycin $(100 \mu \mathrm{g} / \mathrm{ml})$ and $0.1 \%$ BSA. After hanging the tissues with steel needles (TOP, Tokyo, Japan; 8N01B), the individual endometrial tissues were placed into culture glass tubes $(12 \mathrm{~mm} \times 75 \mathrm{~mm}$; Kimble Chase Life Science and Research Products, Vineland, NJ, USA; 73500-13100) containing $2 \mathrm{ml}$ culture medium (DMEM/ Ham's F-12; 1:1 (v/v) [Invitrogen, Carlsbad, CA, USA; 12400-024]) and supplemented with penicillin (100 IU/ml), streptomycin (100 $\mu \mathrm{g} / \mathrm{ml})$ and $0.1 \% \mathrm{BSA}$ under $5 \% \mathrm{CO} 2$ in air. Endometrial tissues were exposed to $\mathrm{Cr}(10-100 \mathrm{nM})$ at $37.5 \mathrm{C}$ for $4 \mathrm{~h}$. At the end of incubation, $1 \mathrm{ml}$ of the conditioned media were collected into 1.5 $\mathrm{ml}$ tubes containing $10 \mu \mathrm{l}$ of a stabilizer solution (0.3 M EDTA, 1\% (W/V) acetylsalicylic acid, $\mathrm{pH} 7.3$ ) and frozen at $-30 \mathrm{C}$. The tissues were blotted on filter paper and weighed to normalize the PGF concentration. The concentrations of PGF in the culture media after incubation were determined by enzyme immunoassay (EIA). The PGF standard curve ranged from $0.016-4 \mathrm{ng} / \mathrm{ml}$, and the ED 50 of the assay was $0.25 \mathrm{ng} / \mathrm{ml}$. The DNA content was used to standardize the PGF concentration in the culture media.

\section{Isolation of endometrial cells}

Early-luteal stage uteri (days 2-5) were used for isolation of endometrial cells. The epithelial and stromal cells from the bovine endometrium were enzymatically separated $(0.05 \%$ collagenase; Worthington Biochemical, Lakewood, NJ, USA; \#CLS1) using procedures described previously [20]. A polyvinyl catheter was inserted into the side of the oviduct, and the ends of the horn were tied to retain trypsin solution used to detach the epithelial cells as described herein. The uterine lumen was washed three times with 30-50 $\mathrm{ml}$ of sterile $\mathrm{Ca}^{2+}$-free and $\mathrm{Mg}^{2+}$-free Hank's balanced salt solution (HBSS) supplemented with $100 \mathrm{IU} / \mathrm{ml}$ of penicillin (Meiji Seika Pharma, Tokyo, Japan; 611400D3051), $100 \mu \mathrm{g} / \mathrm{ml}$ of streptomycin (Meiji Seika Pharma; 6161400D1034) and $0.1 \%$ (w/v) bovine serum albumin (BSA) (Roche Diagnostics, Manheim, Germany; 10735086001). Thirty to fifty milliliters of sterile HBSS containing $0.3 \%$ (w/v) trypsin (Sigma-Aldrich, St. Louis, MO, USA; T9201) was then infused into the uterine lumen through the catheter.

After collection of the epithelial cells, the uterine lumen was washed with sterile HBSS supplemented with antibiotics and $0.1 \%$ (w/v) BSA. The horn was then cut transversely with scissors into several segments, which were slit to expose the endometrial surface. Intercaruncular endometrial strips were dissected from the myometrial layer with a scalpel and washed once in $50 \mathrm{ml}$ of sterile HBSS containing antibiotics. The endometrial strips were then minced into small pieces $\left(1 \mathrm{~mm}^{3}\right)$. The minced tissues $(\sim 5 \mathrm{~g})$ were digested by stirring for $60 \mathrm{~min}$ in $50 \mathrm{ml}$ of sterile HBSS containing $0.05 \%(\mathrm{w} / \mathrm{v})$ collagenase, $0.005 \%(\mathrm{w} / \mathrm{v})$ DNase I (BBI Enzymes, Cardiff, UK; DNP2), and $0.1 \%(\mathrm{w} / \mathrm{v})$ BSA. The dissociated cells were filtered through metal meshes $(100 \mu \mathrm{m}$ and $80 \mu \mathrm{m})$ to remove undissociated tissue fragments. The filtrate was washed three times by centrifugation (10 min at $100 \mathrm{xg}$ ) with Dulbecco's Modified Eagle's Medium (DMEM) (Sigma-Aldrich; D1152) supplemented with antibiotics and $0.1 \%(\mathrm{w} / \mathrm{v})$ BSA. After the washes, the cells were counted using a hemocytometer. The cell viability was greater than $85 \%$ as assessed by $0.5 \%(\mathrm{w} / \mathrm{v})$ trypan blue dye exclusion.

\section{Culture of endometrial stromal cells}

The final pellet of the isolated stromal cells was resuspended in culture medium (DMEM/Ham's F-12; 1:1 (v/v); Invitrogen; 12400-024) supplemented with 10\% (v/v) bovine serum (Invitrogen; 16170078), $20 \mu \mathrm{g} / \mathrm{ml}$ gentamicin (Sigma-Aldrich; G1397) and $2 \mu \mathrm{g} /$ $\mathrm{ml}$ of amphotericin B (Sigma-Aldrich; A9528) [21]. The stromal cells were seeded at a density of $1 \times 10^{5}$ viable cells $/ \mathrm{ml}$ in 24 -well cluster dishes (Greiner Bio-One, Frickenhausen, Germany; \#662160) or $1 \times 10^{5}$ viable cells $/ \mathrm{ml}$ in $75 \mathrm{~cm}^{2}$ culture flasks (Greiner Bio-One; \#658175) for GC-Ra protein determination (Figs. 3-5), and were cultured at $37.5 \mathrm{C}$ in a humidified atmosphere of 5\% $\mathrm{CO} 2$ in air. For the stromal preparation, the medium was changed $2 \mathrm{~h}$ after plating, by which time selective attachment of stromal cells had occurred $[21,22]$. The homogeneity of stromal cells was evaluated using immunofluorescent staining for specific markers of epithelial (cytokeratin) and stromal (vimentin) cells as described previously [23]. Epithelial cell contamination of stromal cells was about $1 \%$. When cells were confluent (6-7 days after the start of the culture), the medium was replaced with fresh DMEM/Ham's F-12 supplemented with $0.1 \%(\mathrm{w} / \mathrm{v}) \mathrm{BSA}, 5 \mathrm{ng} / \mathrm{ml}$ sodium selenite (Sigma-Aldrich; \#S5261), $0.5 \mathrm{mM}$ ascorbic acid (Wako Pure Chemical Industries, Osaka, Japan; 031-12061), $5 \mathrm{mg} / \mathrm{ml}$ transferrin (Sigma-Aldrich; T4132), $2 \mathrm{mg} / \mathrm{ml}$ insulin (Sigma-Aldrich; I-4011) and $20 \mathrm{mg} / \mathrm{ml}$ gentamicin.

Stromal cells were exposed to $\mathrm{Cr}(1-100 \mathrm{nM})$, and P4 (0.1-10 $\mathrm{nM})$ and E2 (0.1-10 $\mathrm{nM})$ for $24 \mathrm{~h}(\mathrm{n}=3)$. After incubation, total RNA was extracted for determination of $G C-R \alpha$ mRNA expression. For protein analysis, the cultured cells were scraped and placed in ice-cold 


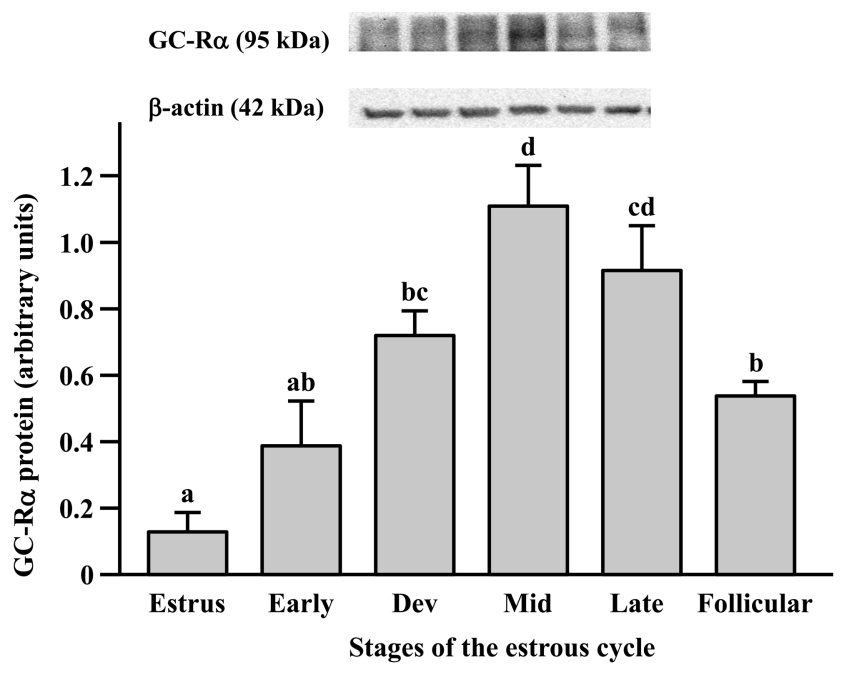

Fig. 1. Expression of GC-R $\alpha$ protein in the bovine endometrium throughout the estrous cycle (estrus, day 0; early, days 2-3; developing [Dev], days 5-6; mid, days 8-12; late, days 15-17; follicular stage, days 19-21). Data are the mean \pm SEM for three samples/stage and are expressed as the relative ratio of GC-R $\alpha$ and ACTB. Representative samples of Western blot for GC-R $\alpha$ and ACTB are shown in the upper panels. Different superscript letters indicate significant differences $(\mathrm{P}<0.05)$, as determined by ANOVA followed by a Fisher's PLSD as a multiple comparison test.

homogenization buffer (25 mM Tris- $\mathrm{HCl}, 300 \mathrm{mM}$ sucrose, $2 \mathrm{mM}$ EDTA, Complete [protease inhibitor cocktail; Roche Diagnostics; 697498], $\mathrm{pH}$ 7.4), frozen in liquid nitrogen and then stored at -80 $\mathrm{C}$ until GC-R $\alpha$ protein analysis by Western blotting.

\section{Western blotting analysis}

GC-R $\alpha$ protein levels in endometrial tissues and stromal cells were assessed by Western blotting analysis. Endometrial tissues were homogenized on ice in the homogenization buffer by a tissue homogenizer (Physcotron; Microtec Do., Chiba, Japan; NS-50), followed by filtration with a metal wire mesh $(150 \mu \mathrm{m})$. For GC-R $\alpha$ protein analysis, nuclei were isolated from the tissue homogenates by centrifugation at $600 \mathrm{x}$ g for $30 \mathrm{~min}$. The cultured stromal cells were lysed in $200 \mu \mathrm{l}$ of lysis buffer (20 mM Tris-HCl, $150 \mathrm{mM}$ $\mathrm{NaCl}, 1 \%$ Triton X-100, 10\% glycerol [Sigma-Aldrich; G7757], Complete, $\mathrm{pH}$ 7.4). Protein concentration was determined by the method of Osnes et al. [24] using BSA as a standard. The proteins were then solubilized in SDS gel-loading buffer (10\% glycerol, 1\% $\beta$-mercaptoethanol [Wako Pure Chemical Industries; 137-06862], $\mathrm{pH}$ 6.8 ), and heated at $95 \mathrm{C}$ for $10 \mathrm{~min}$. Samples (30 $\mu \mathrm{g}$ protein) were subjected to SDS-PAGE (12\%) for $1.5 \mathrm{~h}$ at $200 \mathrm{~V}$. The separated proteins were electrophoretically transblotted to a nitrocellulose membrane (Amersham Biosciences, Piscataway, NJ, USA; RPN78D) for $3 \mathrm{~h}$ at $250 \mathrm{~mA}$ in transfer buffer $(25 \mathrm{mM}$ Tris- $\mathrm{HCl}, 192 \mathrm{mM}$ glycine, 20\% methanol, $\mathrm{pH} 8.3$ ). The membrane was washed in TBS-T $(0.1 \%$ Tween 20 in TBS [25 mM Tris-HCl, pH 7.5, 137 $\mathrm{mM} \mathrm{NaCl}]$ ), incubated in blocking buffer ( $4 \%$ nonfat dry milk in TBS-T) overnight at $4 \mathrm{C}$, incubated at room temperature with a primary antibody specific to each protein (GC-R $\alpha$ antibody [95 kDa; Santa Cruz Biotechnology, Santa Cruz, CA, USA; sc-1002; $1: 200,1 \mathrm{~h}]$ and $\beta$-actin (ACTB) antibody [42 kDa; Sigma-Aldrich; A2228; 1:4,000, $1 \mathrm{~h}]$ ), incubated in blocking buffer for $10 \mathrm{~min}$ at room temperature, washed two times for $10 \mathrm{~min}$ in TBS-T at room temperature, incubated with secondary antibody $[\mathrm{GC}-\mathrm{R} \alpha(1: 10,000)$, anti-rabbit Ig, HRP-linked whole antibody produced in donkey, Amersham Biosciences, NA934; ACTB (1:40,000), anti-mouse Ig, HRP-linked whole antibody produced in sheep, Amersham Biosciences, NA931] for $1 \mathrm{~h}$, washed two times in TBS-T for 10 min and then washed in TBS for $10 \mathrm{~min}$ at room temperature. The signal was detected using an ECL Western Blotting Detection System (Amersham Biosciences; RPN2109).

The intensity of the immunological reaction (GC-R $\alpha$ and ACTB)
A

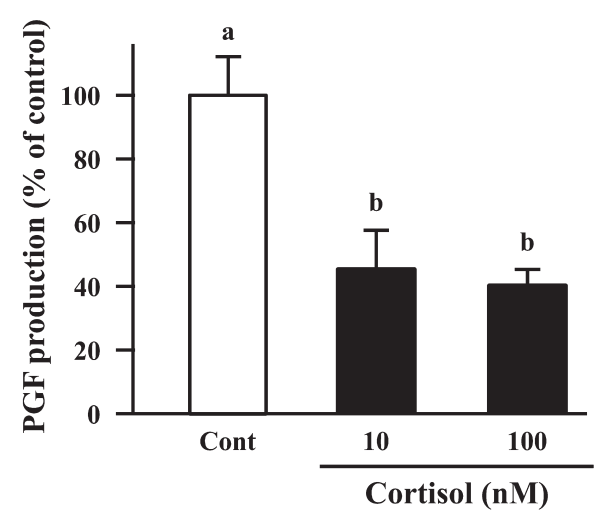

B

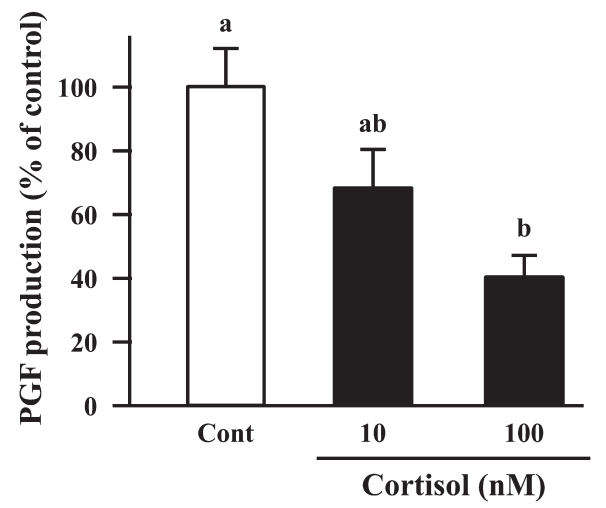

Fig. 2. Effect of $\mathrm{Cr}$ on the production of PGF in cultured bovine endometrium (A) at the mid-luteal stage and (B) at the follicular stage. Endometrial tissues were preincubated for $1 \mathrm{~h}$ in culture medium and then exposed to cortisol (10-100 nM) for $4 \mathrm{~h}$. Different superscript letters indicate significant differences $(\mathrm{P}<0.05)$, as determined by ANOVA followed by a Fisher's PLSD as a multiple comparison test. 

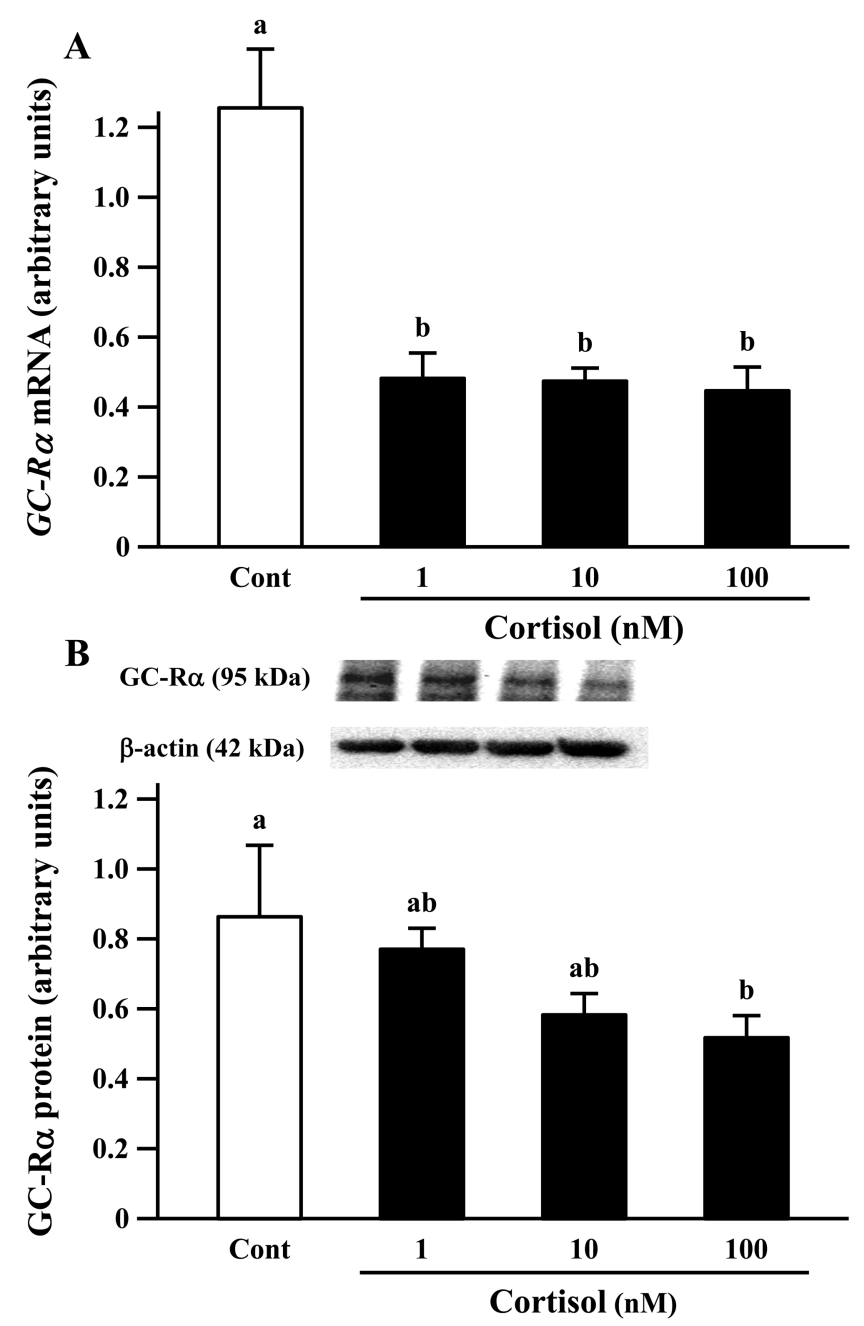

Fig. 3. Effect of cortisol on (A) the amounts of $G C-R \alpha$ mRNA and (B) GC-R $\alpha$ protein expressions in cultured bovine endometrial stromal cells. Endometrial stromal cells were exposed to cortisol $(1-100 \mathrm{nM})$ for $24 \mathrm{~h}$. Data are the mean \pm SEM of four separate experiments performed in triplicate and are expressed as the relative ratio of $G C-R \alpha$ mRNA to $G A P D H$ mRNA (A) and GC$\mathrm{R} \alpha$ to ACTB protein (B). Representative samples of Western blot for GC-R $\alpha$ and ACTB are shown in the upper panels of Fig. 3B. Different letters indicate significant differences $(\mathrm{P}<0.05)$, as determined by ANOVA followed by a Fisher's PLSD as a multiple comparison test.

in the tissues was estimated by measuring the optical density in the defined area by computerized densitometry using NIH Image (National Institutes of Health, USA).

\section{Reverse transcription and real-time PCR}

Total RNA was extracted from endometrial tissue using TRIsure (Bioline, London, UK; \#BIO-38033) according to the manufacturer's directions. Extracted DNA from each sample was quantified using a NanoDrop Lite Spectrophotometer (Thermo Fisher Scientific, Waltham, MA, USA). DNA in the solution was quantified by the absorbance of light $(260 \mathrm{~nm})$ in the spectrophotometer. One microgram of each total RNA was reverse transcribed using a ThermoScript RT-PCR System (Invitrogen), and 10\% of the reaction mixture was used in each PCR using specific primers for GC-R $\alpha$ and GAPDH from the bovine sequence. The primers were chosen using Primer3, an online software package (http://primer3.sourceforge.net/).

Gene expression was measured by real-time PCR using an Mx3000P QPCR System (Stratagene, La Jolla, CA) and a QuantiTect ${ }^{\text {TM }}$ SYBR Green PCR system (Qiagen, Hilden, Germany) starting with 2 ng of reverse-transcribed total RNA as described previously [25]. Briefly, GAPDH expression was used as an internal control. The sequences of the GC-R $\alpha$ primers, 5'- CCATTTCTGTTCACGGTGTG-3' (5' primer, $20 \mathrm{mer}$ ) and 5'-CTGAACCGACAGGGAATTGGT-3' (3' primer, 20 mer), were synthesized according to bovine GC-R $\alpha$ cDNA (GenBank accession number AY238475), and these primers generated a specific 132-base pair (bp) product from all cell types. The primers for GAPDH were 5'-CACCCTCAAGATTGTCAGCA-3' (5' primer, 20 mer) and 5'-GGTCATAAGTCCCTCCACGA-3' (3' primer, 20 mer). These primers generated a specific 103-bp product from all cell types. For quantification of the mRNA expression levels, the primer length $(20 \mathrm{bp})$ and guanine and cytosine contents of each primer (50-60\%) were selected, and PCR was performed under the following conditions: $95 \mathrm{C}$ for $15 \mathrm{~min}$, followed by 55 cycles of $94 \mathrm{C}$ for $15 \mathrm{sec}, 60 \mathrm{C}$ for $20 \mathrm{sec}$, and $72 \mathrm{C}$ for $15 \mathrm{sec}$. Use of the QuantiTect SYBR Green PCR system at elevated temperatures resulted in reliable and sensitive quantification of the RT-PCR products with high linearity (Pearson product-moment correlation coefficient, $r>0.99$ ).

\section{Statistical analysis}

All experimental data are shown as the mean \pm SEM of values obtained in 3-4 separate experiments, in which each experiment was performed in triplicate using stromal cells from a single bovine endometrium. The statistical significance of differences in the effects of $\mathrm{Cr}, \mathrm{P} 4$ and $\mathrm{E} 2$ on GC-R $\alpha$ mRNA and protein expressions and the effects of $\mathrm{Cr}$ on PGF production was assessed by analysis of variance (ANOVA) followed by a Fisher's protected least-significant difference procedure (PLSD) as a multiple comparison test. Statistical significance of differences in GC-R $\alpha$ protein expression was assessed by Student's $t$-test.

\section{Results}

\section{GC-R $\alpha$ protein expression throughout the estrous cycle}

GC-R $\alpha$ protein was detected in the bovine endometrium throughout the estrous cycle ( $\mathrm{n}=3$ cows/stage). GC-R $\alpha$ protein expression was higher at the mid- and late-luteal stages than at other stages (Fig. $1, \mathrm{P}<0.05)$.

\section{Effect of Cr on endometrial PGF production at the mid-luteal stage and at the follicular stage}

$\mathrm{Cr}(10 \mathrm{nM})$ decreased PGF production to $44 \%$ of the control at the mid-luteal stage $(\mathrm{P}<0.05)$, whereas $\mathrm{Cr}$ tended to decrease PGF production to $68 \%$ of the control at the follicular stage $(\mathrm{P}>0.05)$ (Fig. 2). 


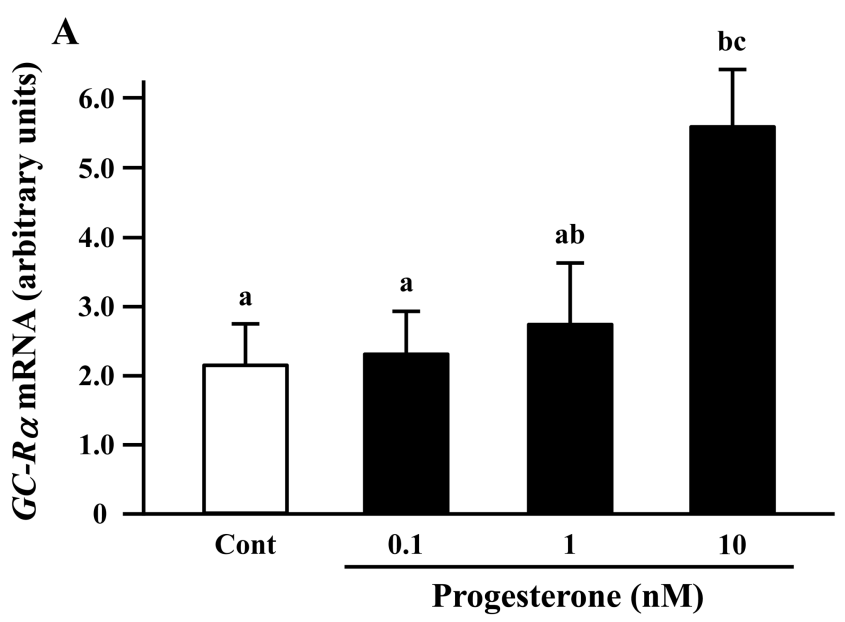

B

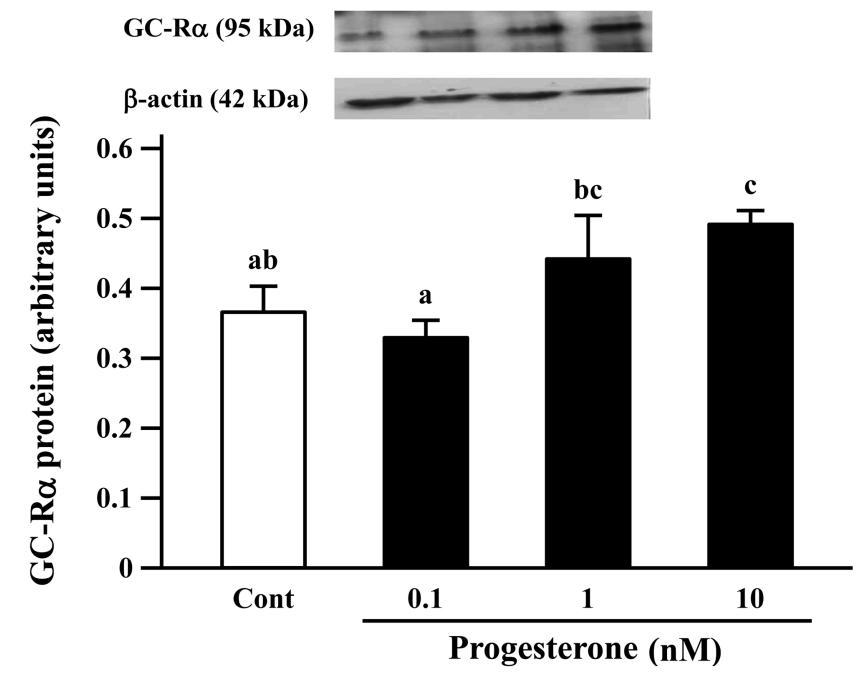

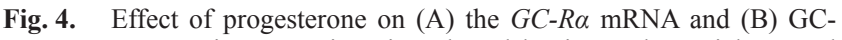
$\mathrm{R} \alpha$ protein expressions in cultured bovine endometrial stromal cells. Endometrial stromal cells were exposed to progesterone $(0.1-10 \mathrm{nM})$ for $24 \mathrm{~h}$. Data are the mean \pm SEM of four separate experiments performed in triplicate and are expressed as the relative ratio of GC-Ra mRNA to GAPDH mRNA (A) and GC$\mathrm{R} \alpha$ to ACTB protein (B). Representative samples of Western blot for GC-R $\alpha$ and ACTB are shown in the upper panels of Fig. 4B. Different letters indicate significant differences $(\mathrm{P}<0.05)$, as determined by ANOVA followed by a Fisher's PLSD as a multiple comparison test.

\section{Effect of $C r, P 4$ and $E 2$ on GC-R $\alpha$ mRNA and protein} expression in cultured bovine endometrial stromal cells

The suppressive effect of $\mathrm{Cr}$ on GC-R $\alpha$ protein was significant at $100 \mathrm{nM}$. However, the suppressive effect of $\mathrm{Cr}$ on $G C-R \alpha$ mRNA expression was apparent at $1 \mathrm{nM}$ in endometrial stromal cells (Fig. 3). P4 increased GC-R $\alpha$ mRNA and protein expression. The effect was significant at $10 \mathrm{nM}$ in cultured bovine endometrial stromal cells (Fig. 4, $\mathrm{P}<0.05$ ). Exposing cultured bovine endometrial stromal cells to E2 did not affect $G C-R \alpha$ mRNA expression (Fig. 5A) but significantly decreased GC-R $\alpha$ protein expression (Fig. $5 \mathrm{~B}, \mathrm{P}<0.05$ ).

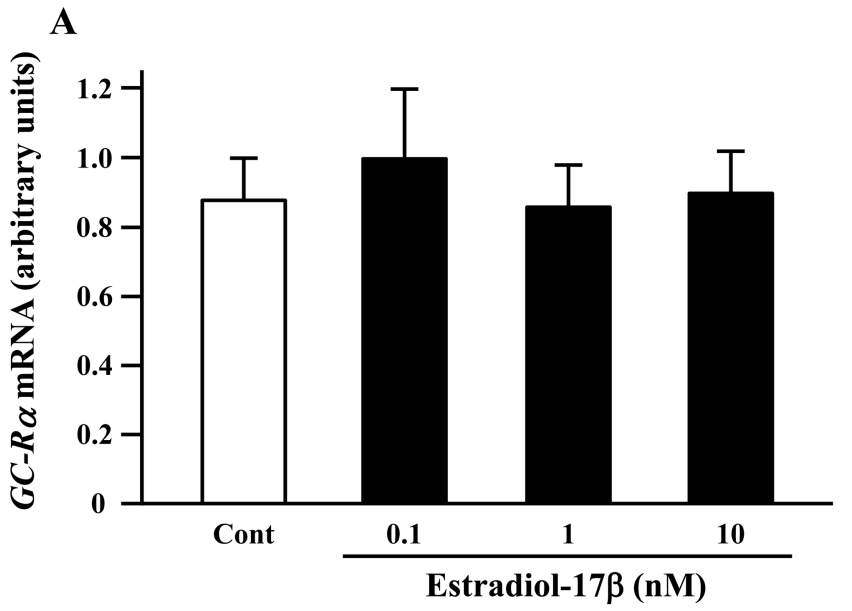

B

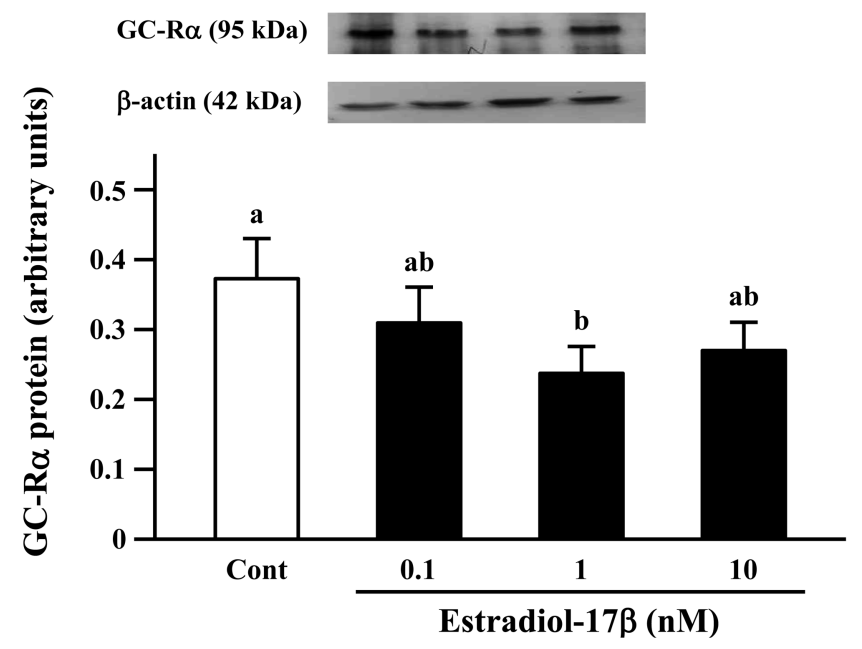

Fig. 5. Effect of estradiol-17 $\beta$ on GC-R $\alpha$ mRNA (A) and protein (B) expression in cultured bovine stromal cells (mean \pm SEM, $n=3$ experiments performed in triplicate). Estradiol-17 $\beta$ (0.1-10 $\mathrm{nM}$ ) was added $24 \mathrm{~h}$ before the end of culture. Data are the mean \pm SEM of four experiments performed in triplicate and are expressed as the ratio of GC-R $\alpha$ to GAPDH mRNA (A) and GC-R $\alpha$ to ACTB protein (B). Representative samples of Western blot for GC-R $\alpha$ and ACTB are shown in the upper panels of Fig. 5B. Different superscript letters indicate significant differences $(\mathrm{P}<0.05)$, as determined by ANOVA followed by a Fisher's PLSD as a multiple comparison test.

\section{Discussion}

The biological action of $\mathrm{Cr}$ is mediated through intracellular GC-R. Two isoforms of GC-R (GC-R $\alpha$ and GC-R $\beta$ ) originate from the same gene by alternative splicing of the GC-R primary transcript [26-28]. Since the ligand-dependent GC-R $\alpha$ stimulates gene transcription in $\mathrm{Cr}$ target tissues, GC-R $\alpha$ is thought to be the active receptor isoform [26]. GC-R $\alpha$ protein was detected in the nuclei of most cell types in the endometrium of cyclic and pregnant cows [29]. In the present study, we examined whether changes in GC-R $\alpha$ expression during the estrous cycle are associated with PGF production in the bovine 
endometrium. The protein expression of GC-R $\alpha$ was significantly higher at the mid-luteal stage than at the other stages. Since PGF production is significantly lower at the mid-luteal stage than at the follicular stage [5], the cyclic changes in GC-R $\alpha$ seem to be associated with the regulation of PGF production in the bovine endometrium. In fact, the suppressive effect of $\mathrm{Cr}$ on PGF production by the bovine endometrial tissue was greater at the mid-luteal stage than at the follicular stage in the present study. These findings suggest that changes in GC-R $\alpha$ expression are relevant for the suppressive effect of $\mathrm{Cr}$ on PGF production in the bovine endometrium.

Glucocorticoids and other steroid hormones downregulate the levels of their cognate receptors in a number of target tissues and in many different cell lines [30,31]. GC-R $\alpha$ was downregulated by its own ligand in different cell types [32,33]. This effect is thought to be a feedback protector mechanism that would avoid deleterious effects of prolonged exposure to a hormone [34, 35]. In the present study, $\mathrm{Cr}$ also inhibited GC-R $\alpha$ mRNA and protein expression in bovine endometrial stromal cells. The above findings suggest that $\mathrm{Cr}$ has a role in regulating GC-R $\alpha$ expression in bovine endometrial stromal cells. Although the plasma concentration of $\mathrm{Cr}$ does not change throughout the estrous cycle [36], the local concentration of $\mathrm{Cr}$ in the bovine endometrium has been suggested to be regulated by the levels of HSD11B [9]. HSD11B protein expression and activity were greater at the follicular stage than at the mid-luteal stage [9]. Thus, the reason why GC-R $\alpha$ expression was low at estrus and at the follicular stage in the present study may be downregulation by a high level of local $\mathrm{Cr}$.

Both P4 and E2 are sex steroid hormones that regulate several female reproductive functions [37]. The GC-R $\alpha$ mRNA [9] and protein expressions observed in our study were highest at the mid-luteal stage in the bovine endometrium. The changes in GC-R $\alpha$ expression throughout the estrous cycle were similar to the cyclic changes in the plasma P4 concentration [2], suggesting that P4 is one of the regulators of GC-R $\alpha$ expression throughout the estrous cycle. In fact, P4 stimulated GC-R $\alpha$ expression in cultured stromal cells in the present study. In contrast to P4, the plasma E2 concentration increases during the follicular stage and reaches a peak at estrus, when endometrial PGF production is higher than at the other stages of the estrous cycle [21]. There is a great difference in the concentrations of P4 and E2 in bovine peripheral blood. The concentrations of P4 and E2 (0.1-10 nM) used in the present study were within the range of the concentrations used in previous studies [38, 39]. E2 has been shown to downregulate GC-R $\alpha$ expression and influence the sensitivity to $\mathrm{Cr}$ in human breast cancer cells [40]. In agreement with these reports, E2 inhibited GC-R $\alpha$ protein, but not $G C-R \alpha$ mRNA expression in cultured bovine endometrial stromal cells in the present study, suggesting that E2 may influence the total amount of GC-R $\alpha$ protein by increasing protein catabolism or by reducing translational efficiency in bovine endometrial stromal cells. Thus, P4 and E2 may regulate PGF production by promoting or suppressing the expression of GC-R $\alpha$, at least in stromal cells.

In conclusion, the findings of this study suggest that the expression of GC-R $\alpha$ is important in regulation of PGF production in the bovine endometrium and that sex steroid hormones and $\mathrm{Cr}$ control the cyclic changes in endometrial PGF production in the bovine endometrium at least in part by regulating GC-R $\alpha$ expression.

\section{Acknowledgments}

We are grateful to Dr S Ito (Kansai Medical University, Osaka, Japan) for antisera of PGF. This research was supported by Grantsin-Aid for Scientific Research (No. 225803188 and No. 19580326) of the Japan Society for the Promotion of Science (JSPS) and by a Grant from the Ministry of Agriculture, Forestry and Fisheries of Japan (Research Program on Innovative Technologies for Animal Breeding, Reproduction, and Vaccine Development (REP-1002).

\section{References}

1. Wolfenson D, Thatcher WW, Drost M, Caton D, Foster DB, LeBlanc MM. Characteristics of prostaglandin $\mathrm{F}$ measurements in the ovarian circulation during the oestrous cycle and early pregnancy in the cow. J Reprod Fertil 1985; 75: 491-499. [Medline]

2. Mann GE, Lamming GE. Timing of prostaglandin F2 $\alpha$ release episodes and oxytocin receptor development during luteolysis in the cow. Anim Reprod Sci 2006; 93: 328-336. [Medline]

3. McCracken JA, Glew ME, Scaramuzzi RJ. Corpus luteum regression induced by prostaglandin F2 $\alpha$. J Clin Endocrinol Metab 1970; 30: 544-546. [Medline]

4. Silvia WJ, Lewis GS, McCracken JA, Thatcher WW, Wilson L Jr. Hormonal regulation of uterine secretion of prostaglandin F2 $\alpha$ during luteolysis in ruminants. Biol Reprod 1991; 45: 655-663. [Medline]

5. Miyamoto Y, Skarzynski DJ, Okuda K. Is tumor necrosis factor $\alpha$ a trigger for the initiation of endometrial prostaglandin F2 $\alpha$ release at luteolysis in cattle? Biol Reprod 2000; 62: 1109-1115. [Medline]

6. Brann DW, Mahesh VB. Role of corticosteroids in female reproduction. FASEB J 1991; 5: 2691-2698. [Medline]

7. Andersen CY. Possible new mechanism of cortisol action in female reproductive organs: physiological implications of the free hormone hypothesis. $J$ Endocrinol 2002; 173: 211-217. [Medline]

8. Duong HT, Piotrowska-Tomala KK, Acosta TJ, Bah MM, Sinderewicz E, Majewska M, Jankowska K, Okuda K, Skarzynski DJ. Effects of cortisol on pregnancy rate and corpus luteum function in heifers: an in vivo study. J Reprod Dev 2012; 58: 223-230. [Medline]

9. Lee HY, Acosta TJ, Tanikawa M, Sakumoto R, Komiyama J, Tasaki Y, Piskula M, Skarzynski DJ, Tetsuka M, Okuda K. The role of glucocorticoid in the regulation of prostaglandin biosynthesis in non-pregnant bovine endometrium. J Endocrinol 2007; 193: 127-135. [Medline]

10. Bamberger CM, Schulte HM, Chrousos GP. Molecular determinants of glucocorticoid receptor function and tissue sensitivity to glucocorticoids. Endocr Rev 1996; 17: 245-261. [Medline]

11. Stewart PM, Mason JI. Cortisol to cortisone: glucocorticoid to mineralocorticoid. Steroids 1995; 60: 143-146. [Medline]

12. Ito K, Chung KF, Adcock IM. Update on glucocorticoid action and resistance. J Allergy Clin Immunol 2006; 117: 522-543. [Medline]

13. Lu NZ, Cidlowski JA. Glucocorticoid receptor isoforms generate transcription specificity. Trends Cell Biol 2006; 16: 301-307. [Medline]

14. Necela BM, Cidlowski JA. Mechanisms of glucocorticoid receptor action in noninflammatory and inflammatory cells. Proc Am Thorac Soc 2004; 1: 239-246. [Medline]

15. Pujols L, Mullol J, Picado C. Alpha and beta glucocorticoid receptors: relevance in airway diseases. Curr Allergy Asthma Rep 2007; 7: 93-99. [Medline]

16. Rhen T, Cidlowski JA. Antiinflammatory action of glucocorticoids-new mechanisms for old drugs. N Engl J Med 2005; 353: 1711-1723. [Medline]

17. Silvia WJ, Taylor ML. Relationship between uterine secretion of prostaglandin F2 $\alpha$ induced by oxytocin and endogenous concentrations of estradiol and progesterone at three stages of the bovine estrous cycle. J Anim Sci 1989; 67: 2347-2353. [Medline]

18. Wathes DC, Hamon M. Localization of oestradiol, progesterone and oxytocin receptors in the uterus during the oestrous cycle and early pregnancy of the ewe. J Endocrinol 1993; 138: 479-492. [Medline]

19. Okuda K, Kito S, Sumi N, Sato K. A study of the central cavity in the bovine corpus luteum. Vet Rec 1988; 123: 180-183. [Medline]

20. Murakami S, Shibaya M, Takeuchi K, Skarzynski DJ, Okuda K. A passage and storage system for isolated bovine endometrial epithelial and stromal cells. J Reprod Dev 2003; 49: 531-538. [Medline]

21. Skarzynski DJ, Miyamoto Y, Okuda K. Production of prostaglandin F2 $\alpha$ by cultured bovine endometrial cells in response to tumor necrosis factor $\alpha$ : cell type specificity and intracellular mechanisms. Biol Reprod 2000; 62: 1116-1120. [Medline] 
22. Fortier MA, Guilbault LA, Grasso F. Specific properties of epithelial and stromal cells from the endometrium of cows. J Reprod Fertil 1988; 83: 239-248. [Medline]

23. Tanikawa M, Lee HY, Watanabe K, Majewska M, Skarzynski DJ, Park SB, Lee DS, Park CK, Acosta TJ, Okuda K. Regulation of prostaglandin biosynthesis by interleukin-1 in cultured bovine endometrial cells. $J$ Endocrinol 2008; 199: 425-434. [Medline]

24. Osnes T, Sandstad O, Skar V, Osnes M, Kierulf P. Total protein in common duct bile measured by acetonitrile precipitation and a micro bicinchoninic acid (BCA) method. Scand J Clin Lab Invest 1993; 53: 757-763. [Medline]

25. Sakumoto R, Komatsu T, Kasuya E, Saito T, Okuda K. Expression of mRNAs for interleukin-4, interleukin-6 and their receptors in porcine corpus luteum during the estrous cycle. Domest Anim Endocrinol 2006; 31: 246-257. [Medline]

26. Hollenberg SM, Weinberger C, Ong ES, Cerelli G, Oro A, Lebo R, Thompson EB, Rosenfeld MG, Evans RM. Primary structure and expression of a functional human glucocorticoid receptor cDNA. Nature 1985; 318: 635-641. [Medline]

27. Encío IJ, Detera-Wadleigh SD. The genomic structure of the human glucocorticoid receptor. J Biol Chem 1991; 266: 7182-7188. [Medline]

28. Oakley RH, Sar M, Cidlowski JA. The human glucocorticoid receptor $\beta$ isoform. Expression, biochemical properties, and putative function. J Biol Chem 1996; 271: 9550-9559. [Medline]

29. Majewska M, Lee HY, Tasaki Y, Acosta TJ, Szostek AZ, Siemieniuch M, Okuda K, Skarzynski DJ. Is cortisol a modulator of interferon tau action in the endometrium during early pregnancy in cattle? J Reprod Immunol 2012; 93: 82-93. [Medline]

30. Svec F, Rudis M. Glucocorticoid hormone receptors in rat pancreas. Biochim Biophys Acta 1981; 674: 30-36. [Medline]

31. Tornello S, Orti E, De Nicola AF, Rainbow TC, McEwen BS. Regulation of glucocorticoid receptors in brain by corticosterone treatment of adrenalectomized rats. Neuroendocrinology 1982; 35: 411-417. [Medline]

32. Kalinyak JE, Griffin CA, Hamilton RW, Bradshaw JG, Perlman AJ, Hoffman AR.
Developmental and hormonal regulation of glucocorticoid receptor messenger RNA in the rat. J Clin Invest 1989; 84: 1843-1848. [Medline]

33. Hoeck W, Rusconi S, Groner B. Down-regulation and phosphorylation of glucocorticoid receptors in cultured cells. Investigations with a monospecific antiserum against a bacterially expressed receptor fragment. J Biol Chem 1989; 264: 14396-14402. [Medline]

34. Okret S, Poellinger L, Dong Y, Gustafsson JA. Down-regulation of glucocorticoid receptor mRNA by glucocorticoid hormones and recognition by the receptor of a specific binding sequence within a receptor cDNA clone. Proc Natl Acad Sci USA 1986; 83: 5899-5903. [Medline]

35. Rosewicz S, McDonald AR, Maddux BA, Goldfine ID, Miesfeld RL, Logsdon CD. Mechanism of glucocorticoid receptor down-regulation by glucocorticoids. $J$ Biol Chem 1988; 263: 2581-2584. [Medline]

36. Dieleman SJ, Bevers MM, Vantol HTM, Willemse AH. Peripheral plasma-concentrations of estradiol, progesterone, cortisol, $\mathrm{LH}$ and prolactin during the estrous-cycle in the cow, with emphasis on the peri-estrous period. Anim Reprod Sci 1986; 10: 275-292.

37. Okuda K, Miyamoto Y, Skarzynski DJ. Regulation of endometrial prostaglandin F2a synthesis during luteolysis and early pregnancy in cattle. Domest Anim Endocrinol 2002; 23: 255-264. [Medline]

38. Kimmins S, Lim HC, Parent J, Fortier MA, MacLaren LA. The effects of estrogen and progesterone on prostaglandins and integrin beta 3 ( $\beta 3$ ) subunit expression in primary cultures of bovine endometrial cells. Domest Anim Endocrinol 2003; 25: 141-154. [Medline]

39. Asselin E, Goff AK, Bergeron H, Fortier MA. Influence of sex steroids on the production of prostaglandins F2 $\alpha$ and E2 and response to oxytocin in cultured epithelial and stromal cells of the bovine endometrium. Biol Reprod 1996; 54: 371-379. [Medline]

40. Krishnan AV, Swami S, Feldman D. Estradiol inhibits glucocorticoid receptor expression and induces glucocorticoid resistance in MCF-7 human breast cancer cells. $J$ Steroid Biochem Mol Biol 2001; 77: 29-37. [Medline] 